\title{
H1-Antihistamines for Allergic Diseases: Old Aged but Not Old-Fashioned Drugs
}

\author{
Luisa Ricciardi', Fabiana Furci and Isola Stefania
}

Allergy and Clinical Immunology Unit, "G. Martino" University Hospital, University of Messina, Italy

*Corresponding author: Luisa Ricciardi, Allergy and Clinical Immunology Unit, G Martino University Hospital, University of Messina, Via Consolare Valeria, 1, 98124 Messina ME, Italy

Histamine is a chemical messenger synthesized from the amino acid histidine by L-histidine decarboxylase. It plays an important role in the system of immunoregulation and in acute and chronic allergic inflammation binding to four subtypes of receptors $\mathrm{H} 1, \mathrm{H} 2, \mathrm{H} 3$ and $\mathrm{H} 4$, described as heptahelical transmembrane molecules that activate specific G-proteins. These receptors placed on the membranes of different cellular jambs (mast cells, endothelial cells, sensory nerve fibres, bronchial smooth muscle) cause different biological actions: Vasodilatation, increased vascular permeability, itching, smooth muscle contraction, coronary spasm, sleep-wake rhythm regulation. Histamine interaction with H1-receptors potentially leads to increasing antigen-presenting cell capacity, release of histamine and other mediators from mast cells and basophils inducing cellular adhesion molecule expression and chemotaxis of eosinophils and neutrophils [1-3].

$\mathrm{H} 1$-antihistamines were introduced for clinical use in 1942 [4] and since then more than $45 \mathrm{H} 1$-antihistamines have been available worldwide representing the largest class of medications used in the treatment of allergic diseases [2]. H1-antihistamines are functionally classified into two groups: First generation and second generation antihistamines. The older, so-called first generation $\mathrm{H} 1$-antihistamines, such as Chlorpheniramine, Diphenydramine, Doxepin, Hydroxyzine after oral or parenteral administration are metabolized in the liver and excreted in large part with the urines. Pharmacological action occurs after 30-60 minutes and persists for about 4-6 hours. First generation antihistamines are characterized by poor receptor selectivity and therefore correlated with side effects such as antimuscarinic, anti-alfa adrenergic and anti-serotoninergic effects [5]. Once introduced systemically they may also cause drowsiness, sedation, and somnolence as a consequence of crossing the blood-brain barrier [6]. Among first generation H1antihistamines chlorpheniramine is, even nowadays, the most used especially for emergency treatment and prevention of severe systemic allergic reactions such as anaphylaxis due to adverse reactions to food, drugs or Hymenoptera [7]. Premedication with chlorpheniramine is also prescribed in association to systemic corticosteroids in patients with a positive history of severe allergic reactions before undergoing surgery [8].

In the 1980s newer second generation $\mathrm{H} 1$ antihistamines were introduced and described as nonsedating. It has been shown that second generation $\mathrm{H} 1$-antihistamines cross the blood-brain barrier to a significantly smaller extent than their predecessors thus decreasing $\mathrm{H} 1$-antihistamine concentration at the level of the central nervous system [2,9]. Recently, it has been shown that a new H1-antihistamine, bilastine, does not cross the blood brain barrier as it is a substrate for P-glycoprotein, a high molecular weight protein, increasing the safety profile of this drug [10].

Second generation $\mathrm{H} 1$-antihistamine administration can be oral, topical nasal, ocular and cutaneous, with a half-life of 24 hours. It has been shown that second-generation $\mathrm{H} 1$-antihistamines inhibit allergy induced inflammation reducing the production of proinflammatory TH2 cytokines such as IL-4 and IL-13 as well as chemokines, interfere with the recruitment

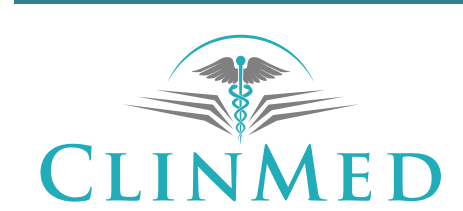

INTERNATIONAL LIBRARY 
of eosinophils in the late phase allergic reaction, down regulate the expression of membrane receptors at the level of nasal epithelial cells and of the vascular endothelium [11]. Among second generation H1antihistamines, cetirizine, loratadine, levocetirizine, desloratadine and rupatadine can be prescribed to patients over 2 years of age, while fexofenadine, mizolastine, ebastineand bilastine can be prescribed only over 12 years of age. The most used topical H1antihistamines are azelastine (ocular and nasal) and ketotifen (ocular) [12].

Second generation $\mathrm{H} 1$-antihistamines are favoured compared to those of the first generation, both in the light of their anti-allergic-anti-inflammatory activity and of their good safety profile [13]. Furthermore, these molecules have been found to be effective both in the treatment of acute allergic episodes and in long-term prophylaxis [14].

In patients with allergic rhinitis, oral secondgeneration $\mathrm{H} 1$-antihistamines prevent and relieve the itching, sneezing and rhinorrhea. Topical nasal H1antihistamine formulations have a more rapid onset of action than oral formulations (e.g. 15 minutes for nasal azelastine vs. 150 minutes for oral desloratadine), usually improving symptoms in patients who are unresponsive to oral $\mathrm{H} 1$-antihistamines and in patients with vasomotor rhinitis $[15,16]$.

In light of the pathophysiological and clinical evidence of the existence of a relationship between the upper and lower airways, the role of H1-antihistamine therapy, as an additional benefit in the control of asthma symptoms in patients with concomitant allergic rhinitis, has been discussed $[17,18]$.

H1-antihistamines are used in patients with urticaria, decreasing itching and reducing the number, size and duration of wheals and flares. Cetirizine and levocetirizine are reported to reduce acute urticaria in young, atopic children $[19,20]$. In general secondgeneration $\mathrm{H} 1$-antihistamines (cetirizine, levocetirizine, loratadine, desloratadine, fexofenadine, bilastine, and rupatadine) reduce symptoms and improve quality of life in patients with chronic urticaria. In these patients, the standard once-daily dose is usually effective but it has been suggested in patients with unresponsive chronic urticaria to progressively increase the dose up to four-fold, because of their safety profiles [21,22].

Oral H1-antihistamines for the treatment of atopic dermatitis is still under discussion, as itching has a complex pathogenesis, which is not only linked to the release of histamine. It has recently been reported that the predominant component of itching in atopic dermatitis is mediated by PAR-2 receptors, present on keratinocytes and on other skin cells and activated by proteases. Furthermore, topical use of $\mathrm{H1}$ antihistamines is also not indicated due to the possible risk of systemic absorption through the skin or the occurrence of contact allergy. Therefore, the use of H1antihistamines in the management of atopic dermatitis is not recommended $[23,24]$.

First generation $\mathrm{H} 1$ antihistamines are also suggested as a prolonged, life-long daily treatment for cutaneous and systemic mastocytosis in order to improve the health of these patients [25].

H1-antihistamines can also be administered in special situations such as pregnancy and breast feeding. In pregnancy there is documented evidence of safety regarding only second-generation $\mathrm{H} 1$-antihistamines. Cetirizine, loratadine and bilastine seem to present a higher safety profile than other second-generation antihistamines, also during breastfeeding. These drugs can be used either on demand, if symptoms occur occasionally, or for prolonged, at least 60 days, in the case of perennial rhinitis or chronic urticaria $[26,27]$.

Topical ocular H1-antihistamines, such as ketotifen or azelastine, can be used in patients with allergic conjunctivitis, improving itching, erythema, tearing and oedema. Ophthalmic formulations have a rapid onset of action (3-15 minutes) and improve also nasal symptoms [28].

H1-antihistamines, therefore, even if they were introduced in the second half of the past century, are still considered up to date for the treatment of acute or chronic allergic reactions and for their prophylaxis [29].

Even in the third millennium the only available parenteral H1-antihistamine is chlorpheniramine, a first generation antihistamine. The current role of second generation $\mathrm{H} 1$-antihistamines, which have outweighed first generation ones, is of first choice for treatment of allergic reactions both, IgE and non-IgE mediated, while new possible uses of these molecules also in non-allergic diseases is to be expected based on the predominantly anti-inflammatory role targeting the immune system [30]. Further studies should also highlight the role played from antihistamines directed against other receptors, in particular on $\mathrm{H} 3$ and $\mathrm{H} 4$ receptors.

$\mathrm{H} 1$-antihistamines are therefore to be considered of great actuality, especially first generation ones, because of their present multiple use, high efficacy and safety standards.

\section{Acknowledgement}

This manuscript is from Prof. Luisa Ricciardi and Dr. Stefania Isola in the memory of their mentor Prof. Francesco Purello D'Ambrosio (1949-2000) who used to give oral presentations on $\mathrm{H} 1$-antihistamines.

\section{References}

1. Simons FE (2004) Advances in $\mathrm{H} 1$-antihistamines. $\mathrm{N}$ Egl J Med 351: 2203-2217. 
2. Simons FE, Simons KJ (2011) Histamine and H1antihistamines: Celebrating a century of progress. J Allergy Clin Immunol 128: 1139-1150.

3. Emanuel MB (1999) Histamine and the antiallergic antihistamines: A history of their discoveries. Clin Exp Allergy 3: 1-11.

4. Halpern BN (1942) Les antihistaminique de synthèse: Essai de chimiothérapie des étatsallergiques. Arch Int Pharmacodyn Ther 68: 339-345.

5. Wyngaarden JB, Seevers MH (1951) The toxic effects of antihistaminic drugs. J Am Med Assoc 145: 277-282.

6. Krystal AD, Durrence HH, Scharf M, Jochelson P, Rogowski $\mathrm{R}$, et al. (2010) Efficacy and safety of doxepin $1 \mathrm{mg}$ and $3 \mathrm{mg}$ in a 12-week sleep laboratory and outpatient trial of elderly subjects with chronic primary insomnia. Sleep 33: 1553-1561.

7. Muraro A, Roberts G, Worm M, Bilò MB, Brockow K, et al. (2014) Anaphylaxis: Guidelines from the european academy of allergy and clinical immunology. Allergy 69: 1026-1045.

8. Hsu Blatman KS, Hepner DL (2017) Current knowledge and management of hypersensitivity to perioperative drugs and radiocontrast media. $\mathrm{J}$ Allergy Clin Immunol Pract 5: 587-592.

9. Simons FE, Simons KJ (2008) H1 antihistamines: Current status and future directions. World Allergy Organ J 1: 145155.

10. Jàregui I, Ramaekers JG, Yanai K, Farré M, Redondo $E$, et al. (2016) Bilastine: A new antihistamine with an optimal benefit-to-risk ratio for safety during driving. Expert Opin Drug Saf 15: 89-98.

11. Holgate ST, Canonica GW, Simons FE, Taglialatela M, Tharp M, et al. (2003) Consensus Group on NewGeneration Antihistamines (CONGA): Present status and recommendations. Clin Exp Allergy 33: 1305-1324.

12. Ben-Eli H, Solomon A (2018) Topical antihistamines, mast cell stabilizers, and dual-action agents in ocular allergy: Current trends. Curr Opinion Allegy Clin Immunol 18: 411416.

13. Kalpaklioglu F, Bacciouglu A (2012) Efficacy and safety of H1-antihistamines: An update. Antiinflamm Antiallergy Agents Med Chem 11: 230-237.

14. Davila I, Del Cuvillo A, Mullol J, Jauregui I, Bartra J, et al. (2013) Use of second Generation H1 antihistamines in special situations. J Investig Allergol Clin Immunol 1: 1-16.

15. Wallace DV, Dykewicz MS, Bernstein DI, Blessing-Moore J, Cox L, et al. (2008) The diagnosis and management of rhinitis: An updated practice parameter. J Allergy Clin Immunol 122: 1-84.
16. Kaliner MA, Berger WE, Ratner PH, Siegel CJ (2011) The efficacy of intranasal antihistamines in the treatment of allergic rhinitis. Ann Allergy Asthma Immunol 106: S6-S11.

17. Bachert C, Maspero J (2011) Efficacy of second generation antihistamines in patients with allergic rhinitis and comorbid asthma. J Asthma 48: 965-973.

18. Dunford PJ, Holgate ST (2010) The role of histamine in asthma. Adv Exp Med Biol 709: 73-80.

19. Church MK, Weller K, Stock P, Maurer M (2011) Chronic spontaneous urticaria in children: Itching for insight. Pediatr Allergy Immunol 22: 1-8.

20. Pite H, Wedi B, Borrego LM, Kapp A, Raap U (2013) Management of childhood urticaria: Current knowledge and pratical recommendations. Acta Derm Venereol 93: 500-508.

21. Zuberbier T, Aberer W, Asero R, Abdul Latiff AH, Baker D, et al. (2018) The EAACI/GA²LEN/EDF/WAO guideline for the definition, classification, diagnosis and management of urticaria. Allergy 73: 1393-1414.

22. Zuberbier $T$ (2012) Pharmacological rationale for the treatment of chronic urticaria with second-generation nonsedating antihistamines at higher-than-standard doses. $J$ Eur Acad Dermatol Venereol 26: 9-18.

23. Darsow U, Wollenberg A, Simon D, Taïeb A, Werfel T, et al. (2010) ETFAD/EADV eczema task force 2009 position paper on diagnosis and tratment of atopic dermatitis. J Eur Acad Dermatol Venereol 24: 317-328.

24. Buddenkotte J, Maurer M, Steinhoff M (2010) Histamine and antihistamines in atopic dermatitis. Adv Exp Med Biol 709: $73-80$.

25. Le M, Miedzybrodzki B, Olynch T, Chapdelaine H, BenShoshan M (2017) Natural history and treatment of cutaneous and systemic mastocytosis. Post Grad Med 129: 896-901.

26. Golembesky A, Cooney M, Boev R, Schlit AF, Bentz JWG (2018) Safety of cetirizine in pregnancy. J Obstet Gynaecol 38: $940-945$.

27. So M, Bozzo P, Inoue M, Elnarson A (2010) Safety of antihistamines during pregnancy and lactation. Can Fam Physician 56: 427-429.

28. Bielory L, Friedlaender MH (2008) Allergic conjunctivitis. Immunol Allergy Clin North Am 28: 43-58.

29. Branco ACCC, Yoshikawa FSY, Petrobon AJ, Safo MN (2018) Role of histamine in modulating the immune response and inflammation. Mediators Inflamm 27: 1-10.

30. Tiligada E, Ishii M, Riccardi C, Spedding M, Simon HU, et al. (2015) The expanding role of immunopharmacology: IUPHAR review 16. Br J Pharmacol 172: 4217-4227. 